Egypt. Acad. J. biolog. Sci., 2 (2): 57- 66 (2010)

Email: egyptianacademic@yahoo.com

Received: 29/6/2010
F. Toxicology \&Pest control

ISSN: 2090 - 0791

www.eajbs.eg.net

\title{
Insecticidal activity of Four Volatile Oils on Two Museum Insects Pests
}

\author{
Reda F.A.Bakr ${ }^{1}$; Hoda M. Abdel Fattah ${ }^{1}$; Nabila M .Salim ${ }^{2}$ and Nagwa H. Atiya ${ }^{2}$ \\ 1-Entomology Department, Faculty of science, Ain Shams University Cairo, Egypt \\ 2-Center of Researches \& conservation of antiquities .Cairo, Egypt
}

\begin{abstract}
Insecticidal effect of volatile oils from peppermint (Mentha piperita), basil (Ocimum basilicum), lemon (Citrus limon) and orange (Citrus sinensis) against two museum insect pests was evaluated by fumigation test. Also, the effect of oils on the antennal segments and their sensilla was studied by using scanning electron microscope. Results of the study revealed that peppermint oil offered the highest toxicity to adults and larvae of the black carpet beetle and cigarette beetle at $\mathrm{LD}_{50}$ level. Larvae of both species were more susceptible than adults to fumigant actions. Among the four volatile oils, the orange oil was less toxic to adult and larvae of both species. Fumigation of the third instar larvae of tested insects with different volatile oils resulted in malformation and disorientation in of the antennal structures and their associated sensilla in the emerged adults.
\end{abstract}

Key words: Volatile plant oil, fumigant, control, Attagenus fasciatus, Lasioderma serricorne

\section{INTRODUCTION}

The black carpet beetle (Attagenus fasciatus) is considered to be a pest in the museums where it attacks organic articles, such as furs, hides, insect specimens, wool articles and oil seeds (Back and cotton, 1936). Cigarette beetle (Lasioderma serricorne) is a pest of stored tobacco, but is also a serious pest of flax, spices, crude drugs, seeds, and most importantly for museums books and dried plants (Rust et al 1996). Insecticidal sprays, dusts or vapours are commonly applied for control of museum pests. Such application may be harmful to museum articles (Dawson 1988). Generally, usage of synthetic insecticides has resulted in polluted environment, toxicity to non-target organisms, pest resistance and pesticide residues (Shaaya et al. 1997 and Ogendo et al. 2003). Naturally occurring substances are an alternative to conventional pesticides and plant essential oils have traditionally been used to kill insects (Isman 2000). Plant essential oils are considered as insect-control agents because their bioactive chemicals are selective and have little or no harmful effect on the environment and non-target organisms (Zettler 1991).

Insect antenna is a major channel of sensory input, including receptors for volatile odors and pheromones (Ehmer, and Gronenberg, 1997 and Renthal, 2003). Sex pheromones play an essential role in the mating behavior of various storage beetles including the black carpet beetle (Burkholder, 1983). Moreover, antennal sensilla can play an important role in the insect pest control. Volatile oil can disrupt communication in mating behavior of insect by blocking the function of antennal sensilla and unsuccessful mating could lead to a lower fecundity and ultimately lower the population of insect pest (Ahmed et al., 2001).

The aim of the present study is to evaluate the toxicity of four plant volatile oils through fumigation against adults and larvae of the black carpet beetle and 
the cigarette beetle under laboratory conditions. Also, detect the effect of these oils on the morphology of adult antennae and its associated sensilla, when $A$. fasciatus and $L$. serricorne treated as third instar larvae by the Scanning electron microscopy.

\section{MATERIALS AND METHODS Insect culture:}

The culture of the black carpet beetle (A. fasciatus) was obtained from Department of Zoology, Faculty of Science, Minia University and the culture of the cigarette beetle (L. serricorne) was obtained from Department of Entomology, Faculty of Science, Ain Shams University. The insects were reared in their rearing media for several generations under laboratory conditions (50-55\% RH and 27-30 $\mathrm{C}^{\circ}$ ).

Volatile oils:

Four commercially available volatile oils were tested in this study. Peppermint oil (Mentha piperita, F: Labiatae), basil oil (Ocimum basilicum F: Lamiaceae), lemon oil (Citrus limon, F: Rutaceae and orange oil (Citrus sinensis, F: Rutaceae). All the tested oils were purchased as pure oil (Branded in Egypt) from Pharaonic Company of medicinal and aromatic oils and Nabet Company. The oils were extracted from the dried plants by steam distillation.

\section{Fumigation test:}

Series of dilutions of the volatile oils were prepared using acetone as a solvent. Filter papers (Whatman No.1) were treated with $1 \mathrm{ml}$ of the concentrations of each oils and placed on the inner surface of the cover of $80 \mathrm{~mm}$ Petri-dish. Twenty five larvae or adults of each species were put in the Petri-dish and finally the dishes were made air tight. Controls were treated with acetone only. Each treatment or control was replicated four times. After 24 hours of fumigation, larvae and adults mortality was recorded.

\section{Examination with the Scanning Electron Microscopy (SEM):}

Fresh specimens of the black carpet beetle and cigarette beetle adults from a colony maintained in the laboratory (untreated) and adults resulted from treatment of third instar larvae with different oils were used. They were dried in the chamber of the scanning electronmicroscope; a schematic representation of a SEM. the electron column accelerates and focuses a beam of electrons into the sample surface. Interactions between the sample and the beam electrons cause a variety of signals emissions. The signals are detected and reconstructed into a virtual image displayed on a CRT.

\section{Data analysis:}

Mortality data were corrected using Abbott's formula (Abbott 1925). The observed data were subjected to probit analysis according to probitvb6.

\section{RESULTS AND DISCUSSION}

\section{Fumigation toxicity bioassay:}

$\mathrm{LC}_{50}$ and $\mathrm{LC}_{95}$ values of the volatile plant oils tested are summarized in Table 1 and these values revealed that the most effective volatile oil against the black carpet beetle (A. fasciatus) larvae and adults was peppermint oil, the same as for the cigarette beetle (L. serricorne). Larvae of both species were more susceptible than adults to fumigant toxicity of all the four oils (Table 1). Results also revealed that the black carpet beetle was more susceptible to the tested volatile oil than the cigarette beetle. LC50s values of peppermint oil against larvae and adults of the black carpet beetle were 1.093 and $1.673 \mathrm{ml} /$ $80 \mathrm{~cm}^{3}$, respectively, compared with $1.279 \mathrm{ml} / 80 \mathrm{~cm}^{3}$ and $1.799 \mathrm{ml} / 80 \mathrm{~cm}^{3}$ for the larvae and adults of cigarette beetle, respectively (Table 1). Among the four volatile oils, orange oil was less toxic to adult and larvae of both species.

Volatile compounds of many plant extracts and essential oils consist of 
alkanes, alcohols, aldehydes, and terpenoids, especially monoterpenoids, and exhibit fumigant activity (Coats et al. 1991, Ahn et al. 1998, Kim and Ahn 2001, Kim et al. 2003). Our study demonstrated that all the tested volatile oils were effective against the black carpet beetle and cigarette beetle without direct contact. These results indicated that the mode of delivery of the oils was largely caused by action in the vapor phase: they may be toxic through penetration via the respiratory system.
The present study show that peppermint oil was generally a more effective fumigant against the larvae and adults of the black carpet beetle and cigarette beetle. Peppermint oil is one of the monoterpenes that can be toxic via penetration of the insect cuticle or the respiratory system (prates et al., 1998). There are numerous reports on the insecticidal activity of the volatile oils from peppermint species (Klingauf et al., 1983 and Shaaya et al., 1991).

Table 1: Insecticidal effect of four volatile plant oils on A. fasciatus and L. serricorne.

\begin{tabular}{|c|c|c|c|c|c|c|c|}
\hline \multirow{2}{*}{$\begin{array}{c}\text { Insect } \\
\text { Species }\end{array}$} & \multirow{2}{*}{$\begin{array}{l}\text { Life } \\
\text { stage }\end{array}$} & \multirow[t]{2}{*}{ Oils } & \multirow{2}{*}{$\begin{array}{c}\mathrm{LD}_{95} \\
(1 \mathrm{ml} / \\
\left.80 \mathrm{~cm}^{3}\right)\end{array}$} & \multirow{2}{*}{$\begin{array}{c}\mathrm{LD}_{50} \\
(1 \mathrm{ml} / \\
\left.80 \mathrm{~cm}^{3}\right)\end{array}$} & \multicolumn{2}{|c|}{ Fiducial limits } & \multirow{2}{*}{ Regression equation } \\
\hline & & & & & Upper & Lower & \\
\hline \multirow{8}{*}{ A. fasciatus } & \multirow{4}{*}{ Larva } & $\begin{array}{l}\text { Peppermint } \\
\text { oil }\end{array}$ & 4.336498 & 1.09342 & 1.20875 & 0.97847 & $\begin{array}{c}\mathrm{Y}=0.1066371 \\
+2.749065 \mathrm{x}\end{array}$ \\
\hline & & Basil oil & 8.190686 & 1.78786 & 1.98270 & 1.61698 & $\begin{array}{c}\mathrm{Y}=0.6279486 \\
+2.488556 \mathrm{x}\end{array}$ \\
\hline & & Lemon oil & 8.530019 & 1.87686 & 2.08490 & 1.69681 & $\begin{array}{c}Y=0.6840389 \\
+2.50168 x\end{array}$ \\
\hline & & Orange oil & 10.30857 & 2.10117 & 2.36619 & 1.88187 & $\begin{array}{c}\mathrm{Y}=0.7679036 \\
+2.381373 \mathrm{x}\end{array}$ \\
\hline & \multirow{4}{*}{ Adult } & $\begin{array}{l}\text { Peppermint } \\
\text { oil }\end{array}$ & 6.320686 & 1.67251 & 1.82938 & 1.52957 & $\begin{array}{c}Y=0.6363473 \\
+2.848838 x\end{array}$ \\
\hline & & Basil oil & 9.927328 & 2.05647 & 2.308631 & 1.84592 & $\begin{array}{c}\mathrm{Y}=0.7533264 \\
+2.405847 \mathrm{x}\end{array}$ \\
\hline & & Lemon oil & 11.10568 & 2.25222 & 2.555307 & 2.00675 & $\begin{array}{c}\mathrm{Y}=0.8370376 \\
+2.373821 \mathrm{x}\end{array}$ \\
\hline & & Orange oil & 11.22772 & 2.25550 & 2.561502 & 2.008181 & $\begin{array}{c}\mathrm{Y}=0.8335875 \\
+2.359809 \mathrm{x}\end{array}$ \\
\hline \multirow{8}{*}{ L. serricorne } & \multirow{4}{*}{ Larva } & $\begin{array}{c}\text { Peppermint } \\
\text { oil }\end{array}$ & 4.758 & 1.2788 & 1.400 & 1.16063 & $\begin{array}{l}Y=0.3708949 \\
+2.882424 x\end{array}$ \\
\hline & & Basil oil & 7.7357 & 1.6609 & 1.839 & 1.50103 & $\begin{array}{c}Y=0.5425248 \\
+2.461925 \mathrm{x}\end{array}$ \\
\hline & & Lemon oil & 9.5809 & 1.9403 & 2.1724 & 1.74373 & $\begin{array}{l}\mathrm{Y}=0.682792 \\
+2.371784 \mathrm{x}\end{array}$ \\
\hline & & Orange oil & 10.0416 & 2.07656 & 2.3334 & 1.86278 & $\begin{array}{c}\mathrm{Y}=0.7626472 \\
+2.403214 \mathrm{x}\end{array}$ \\
\hline & \multirow{4}{*}{ Adult } & $\begin{array}{c}\text { Peppermint } \\
\text { oil }\end{array}$ & 9.75014 & 1.79996 & 2.01929 & 1.61182 & $\begin{array}{l}\mathrm{Y}=0.572248 \\
+2.241783 \mathrm{x}\end{array}$ \\
\hline & & Basil oil & 10.4146 & 2.01459 & 2.2696 & 1.80250 & $\begin{array}{c}\mathrm{Y}=0.7013126 \\
+2.305534 \mathrm{x}\end{array}$ \\
\hline & & Lemon oil & 11.59064 & 2.12694 & 2.41822 & 1.89083 & $\begin{array}{c}Y=0.7321616 \\
+2.233855 x\end{array}$ \\
\hline & & Orange oil & 10.56887 & 2.17299 & 2.45323 & 1.94308 & $\begin{array}{c}\mathrm{Y}=0.8070623 \\
+2.394428 \mathrm{x}\end{array}$ \\
\hline
\end{tabular}

The external morphology and types of sensilla on the antenna of $A$. fasciatus

According to Kalik (2006), The antenna of $A$. fasciatus consisted of 11 segments, antennal club 3 segmented with short setation, segment ix and $\mathrm{x}$ asymmetrically triangular, antennal club as long as remaining segments combined (Fig. 1) .
As shown in Figure 2 different types of sensilla are presented in the antennal club segment. Sensilla trichoid 1(ST1) are sharp-tipped hairs with strong longitudinal grooves and slightly curved toward the antennal shaft. The hairs bases inserted tightly into a small cuticular socket.

The ST1 is the most aboundant sensilla type on the antennal club 
segments of A. fasciatus (Fig. 1), Sensilla trichoid 2 (ST2) are straight hair located tightly in a small socket (Fig. 2). Sensilla basiconica 1 (SB1) are short and characterized by smooth cuticle and a straight blunt tip. They are set into a tight socket. Sensilla basiconica2. (SB2) these short pegs are situated mostly on the lateral side of the segment, they are inserted into a wide socket. Sensilla styloconicum (SS) are few in number.

Sensilla trichoid 1 described in the current study are similar to the sensilla described in several insects (Isidoro and Solinas, 1992 and Said et al., 2003). In different coleopteran beetles, sensilla trichod proven to have olfactory function (Kim and Yamasaki, 1996; Lopes et al., 2002 and $\mathrm{Hu}$ et al., 2008).

The number of ST1 are more abundant sensilla on the antennae, it might be indicate that these sensilla have an olfactory function.

Sensilla trichoid 2 resemble sensilla trichodea 2 on the antennae of the ground beetle, Bembidion properans Steph (Merivee et al., 2002). In male moths, trichoid sensilla respond to female sex pheromone related compounds (Zacharuk, 1985; Hallberg et al., 1994; Faucheux et al., 2006).

The sensilla basiconica 1 resemble the sensilla basiconica type 1 in the eucalyptus wood borer, Phoracantha semipunctata (Lopes et al., 2002) while sensilla basiconica similar to the sensilla basiconica type 2 in Hydrotaea chalcogaster (Sukontason et al., 2007). According to Merivee et al., 1998 and 1999, Sensilla trichoid 2 have a sexpheromone receptor role.

The external morphology and types of sensilla on the antenna of $L$. serricorne:

The antenna of the cigarette beetle adult consisted of a bean- shaped scape (Sc), a small pedicel $(\mathrm{Pe})$ and nine flagellar segments (F1 1-9) (Fig.1). The outline of the whole antenna appears serrated due to the triangular- shaped segments while the terminal segment is ellipsoid (Fig 1).

Six distinctly- shaped sensilla were observed on the flagellar segments (Fig. 4). Sensillum basiconicum (SB) are distributed over the distal and lateral regions of segments. Sensillium styloconicum (SS) are few in number and distributed in the distal region of the segments. According to Levinson and Levinson (1987), flagellar sensilla on the male antenna of $L$. serricorne are classified into six types based on antennal criteria. In their classification S. basiconica on the male antenna were sub classified into long \& short types. Sensilla that are supposed to have olfactory function are S. Basiconicum and S. Styloconicum. A male antenna responded to the sex pheromone, while responded only weakly to general odors (Chman et al., 1982, Okada, unpblished data). Their findings suggest that the antenna of the male cigarette beetle is highly specialized for detecting the sex pheromone produced by the female, and most of its olfactory sensilla are turned for the sex pheromone.

The Sensilla chaetica(SC), these sensilla commonly seen in different insects (Merivee et al., 2002 ; Roux et al., 2005 and Onagbola and Fadamiro, 2008). Based on the location and structure of this type of sensilla, it is believed to have a dual function of mechanoreception and contact chemoreception (Isidoro and Solinas, 1992; Jourdan et al.,1995).

The grooved pegs (GP), the probable function of these sensilla is chemo- or thermoreception (Zacharuk, 1985). Also, Bartlet et al. (1999) described an olfactory/thermoreceptive function .

\section{Effect of volatile oils on antennae and their sensilla:}

In the presented study, Treatment of $3^{\text {rd }}$ instar larvae of $A$. fasciatus with peppermint oil resulted in malformation 
and disorientation of the antennal structures of emerged adults (Fig. 5 and $6)$.

Also, treatment of $3^{\text {rd }}$ instar larvae of L. serricorne with peppermint oil resulted in malformation of the antennal segments and their associated sensilla and enlarge membranous joint between segments in the emerged adults (Fig. 7). The antennae function as directional chemoreceptors, deformation of the antennal hairs stretches the membrane jointing the hair to the cuticle (Smola., 1970).

In the present study, peppermint oil caused abnormalities in the shape of antennal sensilla especially trichoid sensilla in males of $A$. fasciatus and $L$. serricorne (Fig. 6\& 7) which specific for the female sex phetomones.

Peppermint oil is lipophilic in properties and accumulates with lipids, it had a strong morphogenic effect acting by fumigation and disrupting adult development.

The toxic and morphological inhibitory effects of peppermint oil may be due to suffocation and inhibition of various biosynthesis processes of the insects at developmental stages. Formation of malformed individuals is reported to be physiological effect of plant extract as reported by Redfern et al. (1982). Mesbah et al. (2006) reported that all the efficiency tested essential and/ or volatile oils acted principally as insect growth inhibitors causing disruption of insect development and abnormal adults that were lead finally to death. Insect growth regulators inhibit synthesis of chitin by causing abnormal endocuticular deposition and absorptive moulting (Post and Vincent, 1973).

The undesirable effects of peppermint oil on the structure of antenna and their associated sensilla may cause failure of treated males to mate with female and ultimately lower the population of insect pest.
These studies suggest that peppermint oil may be potential fumigant against museum pests.

\section{REFERENCES}

Ahmed, $\quad$ k.s.yosui,Y.and Lachikawa,T.(2001): Effect of neem oil on mating and oviposition behavior of azuki bean weevil, callosobrucus chinensis L.( coleoptera: Bruchidae). Pakistan J. Of Biological sciences ,4(11): 13711373.

Ahn, Y. J., S. B. Lee, H. S. Lee, and G. H. Kim. Insecticidal and acaricidal activity of carvacrol and $\beta$ thujaplicine derived from Thujopsis dolabrata var: hondai sawdust. J. Chem. Ecol 1998. 24:81-90.

Back, E.A. and R.T.Cotton (1938): The black carpet beetle, Attagenus piceus (Oliv.). J. Econ. Entoml. 31: 280286.

Burkholder, E.W., 1983. Bio-monitoring of stored product insects. In: Mitchell, E.R. (ed.), Management of Insect Pest with Semiochemicals, Pp: 2940.

Chuman,T.,K.

Mochizuki,M.Mori,M.Kohno,K.Kat

o,H.Nomi and K,Mori (1982):

Behavioral and electroantennogram responses of male cigarette beetle (lasioderma serricorne $\mathrm{F}$.) to optical active serricornins. Agric. Biol. Chem. 46:3109-3112.

Coats, J.R., Karr, L.L., Drewes, C.D. 1991.Toxicity and neurotoxic Effects of monoterpenoids in insects and earthworms. In: Hedin P. A.(Ed.), Naturally Occuring Pest Bioregulators. ACS (AmericanChemicalSociety), Washington,DC, pp.305- 316.

Dawson, J. 1988. The effects of insecticides on museum artifacts and materials, pp. 135-150. In L.A. Zycherman and J. R. Schrock [eds.], A guide to museum pest control, Assoc. of Syst. Collections. Washington, D.C.

Ehmer, B. and Gronenberg, W. (1997): Proprioceptors and fast antennal reflexes in the ant Odontomachus 
(Formicidae, Ponerinae). Cell and Tissue Research 290: 153-165.

Hallberg, E., Hansson, B.S. \& Steinbrecht, R.A. 1994. Morphological characteristics of antennal sensilla in the european cornborer Ostrinia nubilalis (Lepidoptera: Pyralidae). Tissue and Cell, 26, 489-502.

$\mathrm{Hu}, \mathrm{Q}, \mathrm{Kwon}, \mathrm{Y}-\mathrm{S}$, Nunez, E, Cardamone, MD, Hutt, KR and Ohgi, KA (2008). Enhancing nuclear receptor-induced transcription requires nuclear motor and LSD1-dependent gene networking in interchromatin granules. Proc Natl Acad Sci USA 105, 19199-204.

Isidoro, N., Solinas, M., 1992. Functional morphology of the antennal chemosensilla of Ceutorhynchus assimilis payk. (Coleoptera: Curculionidae). Entomologica(Bari) 27:69-84.

Isman, M.B. (2000): Plant essential oils for pest and disease management. CropProtection, 19: 603-608.

Jourdan, H., Barbier, R.,Bernard, J., Ferran, A., 1995. Antennal sensilla and sexual dimorphism of the adult ladybird beetle Semiadalia undecimnotata schn. (Coleoptera: Coccinellidae). Int.J.Insect Mophol.Embryol.24: 307-322.

Kim, S. I., O. K. Shin, C. Song, K. Y. Cho, and Y. J. Ahn. 2001b. Insecticidal activities of aromatic plant extracts against four agricultural insects. Agric Chem Biotechnol 44:23-26.

Kim, J. L., Yamasaki, T., 1996. sensilla of carabus (Isiocarabus) Fiduciarius saishutoicus Csiki (Coleoptera: Carabidae). Int. J. Insect Morphpl. Embryol. 25:153-172.

Kim, S. I., Park, C., Ohh, M. H., Cho, H. C., Ahn, Y. J., 2003. Contact and fumigant activities of aromatic plants extracts and essential oils against Lasioderma serricorne (Coleoptera: Anobiidae). Journal of Stored Products Research 39: 11-19.

Klingauf, f., Bestman, H.J.,Vostrowsky,O. And Michaelis,k.(1983): the effect of essential oils on insect pests . mitteilugen der deutschen gesell schaft fur allgemeine and angewandte Entomologie , 4:123126.

Levinson, H. Z. and Levinson, A. (1987). Pheromone biology of the tobacco beetle, Lasioderma serricorne F., Anobiidae with notes on the pheromone Antagonism between 4s, 6s, 7sand $4 \mathrm{~s}, 5 \mathrm{~s}, 7$ R- serricornin 103 : 217- 240 .

Lopes, O.,Barata,E.N.,Mustaparta,H., Araujo,J.,2002. Fine structure of antennal sensilla basiconica and their detection of plant volatiles in the eucalyptus wood borer, phoracantha semipunctata Fabricius (Coleoptera

Cerambycidae). Arthropod struct. Dev. 31: 1-13.

Merivee, E., Ploomi, A., Rahi, M.., Bresciani, J., Ravn, Hp, Luik, A., Sammenelseg, V., 2002. Antennal sensilla of the ground beetle Bembidion properans Steph. (Coleoptera Carabidae). Micron 33: 429-440.

Mesbah, H.A.; Mourad, A.K. Rokaia, A.Z. (2006): Efficacy of some plant oils alone/ or combined with different insecicideson the cotton leaf-worm Spodoptera littoralis (Boisd.) (Lepidoptera: Noctuidae) in Egypt. Commun. Agric. Appl. Biol. Sci., 71: 305-328.

Ogendo, J. O.; Belmain, S.R.; Deng, A.L.; Walker, D.J. (2003): Comparison of toxic and repellent effects of Lantana camara L. with Tephrosia vogelii Hook and a synthetic pesticide against Sitophilus zeamais Motschulsky in maize grain storage. Insect 
Science and Its Application 23: 127-135.

Okada, K., Mori, M., Shimazaki, K., Chuman, T., 1992. Morphological studies on the antennal sensilla of the cigarette beetle, Lasioderma serricorne (F.) (Coleoptera: Anobiidae). Jpn. J. Appl. Entomol. Z 27: 269-276.

Onagbola, E.O. and Fadamiro, H.Y. 2008. Scanning electron microscopy studies of antennal sensilla of Pteromalus cerealellae (Hymenoptera: Pteromalidae). Micron 39: 526-535.

Post, L.C. and Vincent, W. R. (1973): A new insecticide chitin synthesis. Nature Wissenschaften 60: 431432.

Prates, H. T., santos, J. P., waquil, J. M., Fabris, J. D., oliveria, A. Band foster. J. E.(1998): reflexes in the ant Odontomacus (Formicidae, Ponerinae). Cell Tissue, 290,153.

Redfern, R. E.; Kelly, T. J.; Borkovees, A. B. and Hayes, D.K. (1982): Ecdysteroid titers and moulting aberration in last stage Oncopeltus nymphs, treated with IGR's pesticides. Biochem. Physiol., 118 93): 351-356.

Renthal, R. (2003): Structure and distribution of antennal sensilla of the red imported fire ant. Micron, 34(8): 405.

Roux, O., van Baaren, J., Gers, C., Arvanitakis, L., Legal, L., 2005. Antennal structure and ovipostion behavior of the Plutella xylostella specialist parasitoid Cotesia plutellae. Micro. Res. Technol. 68: 36-44.

Rust, M. K., V. Daniel, J. R. Druzik, and F. D. Preusser (1996): The feasibility of using modified atmospheres to control insect pests in museums. Restaurator 17:43-60.

Shaaya, E.; E. Ravid, N. Paster, B. Juven, U. Zisman and V .Pissarau ,1991. Fumigant toxicity of essential oils against four major stored product insects. In: Int. J. Tropical insect. sci., 21:61-66.

Shaaya, E., Kostjukovski, M., Eilberg, J., Sukprakarn, C. (1997): Plant oils as fumigants and contact insecticides for the control of stored- product insects. Journal of Stored Products Research 33: 715.

Smola, U. (1970). Untersuchung zur Topographie, Mechanik und StröSmungsmechanik der Sinneshaare auf dem Kopf der Wanderheuschrecke Locusta migratoria. Z. vergl. Physiol. 67, 382-402.

Zacharuk, R.Y., 1985. Antennae and Sensilla. In: Kerkut, G.A., Gilbert, L. I. (Eds.), Comparative Insect Physiology, Biochemistry and Pharmacology, vol. 6. Pergamon Press, Oxford, pp. 169.

Zettler, J. L. (1991): Pesticide resistance in Tribolium castaneum and Tribolium confusum (Coleoptera, Tenebrionidae) from flour mills in the United States. Journal of Economic Entomology, 84:763767.

Tribolium confusum (Coleoptera, Tenebrionidae) from flour mills in the United States. Journal of Economic Entomology, 84:763767. 


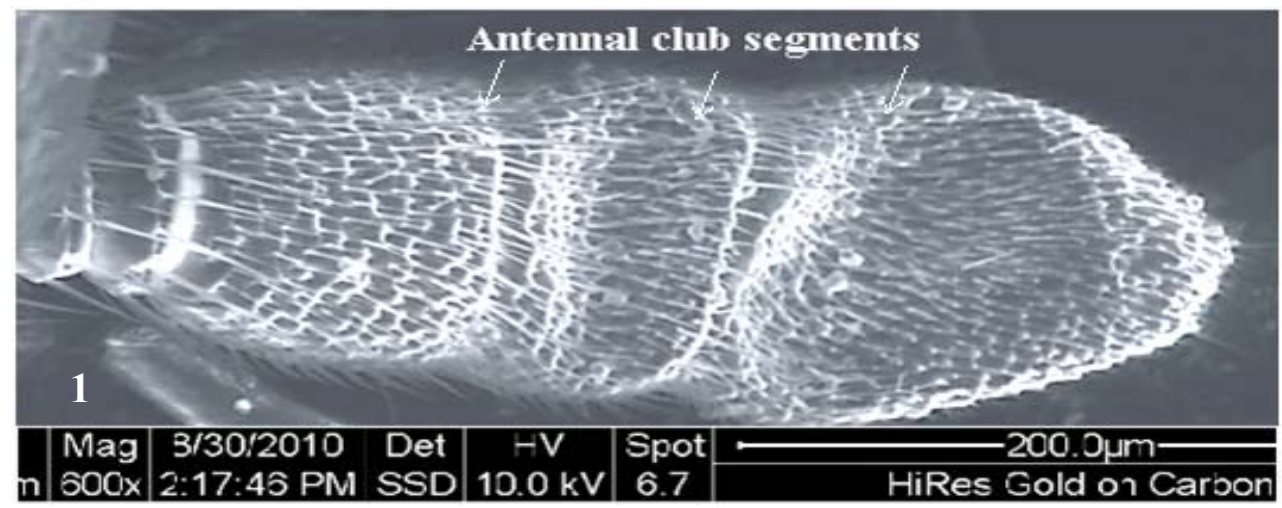

Fig.1. Scanning electron micrograph of antennal club segments of untreated A. fasciatus. Scale bar: $200 \mu \mathrm{m}$.

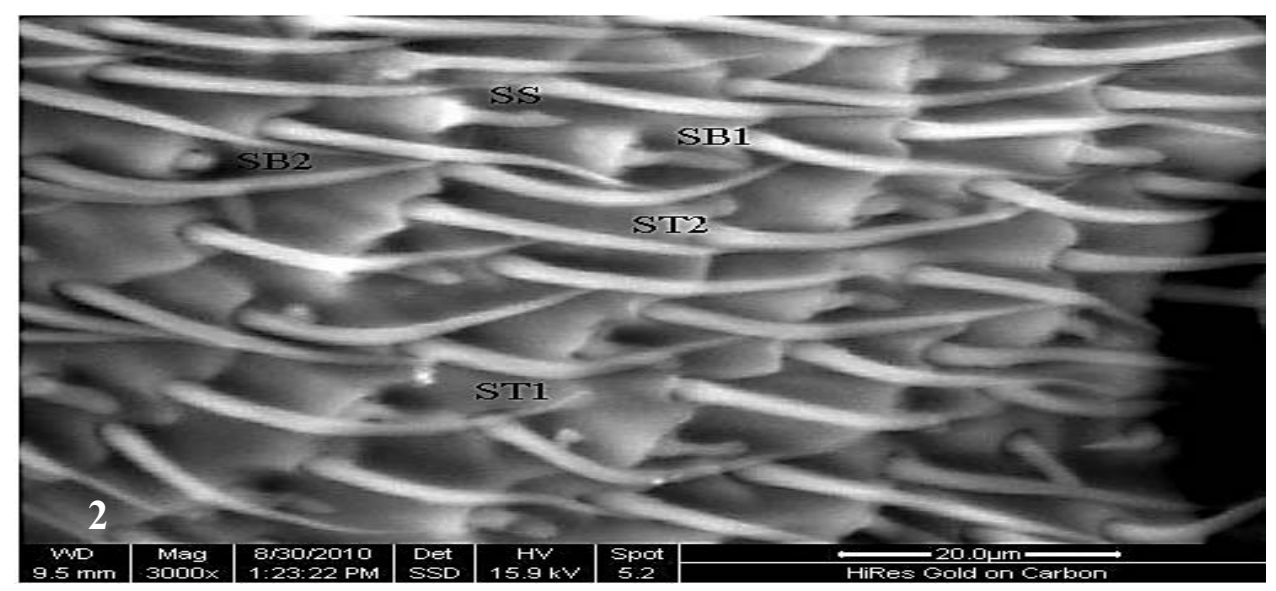

Fig. 2: Scanning electron micrograph of antennal club segment 2 of untreated A. fasciatus showing: SS (Sensilla styloconicum), ST1 (Sensilla trichoid 1) and ST2 (Sensilla trichoid 2), SB1 (Sensilla basiconica.1) and SB2 (Sensilla basiconica.2) Scale bar: $20 \mu \mathrm{m}$.

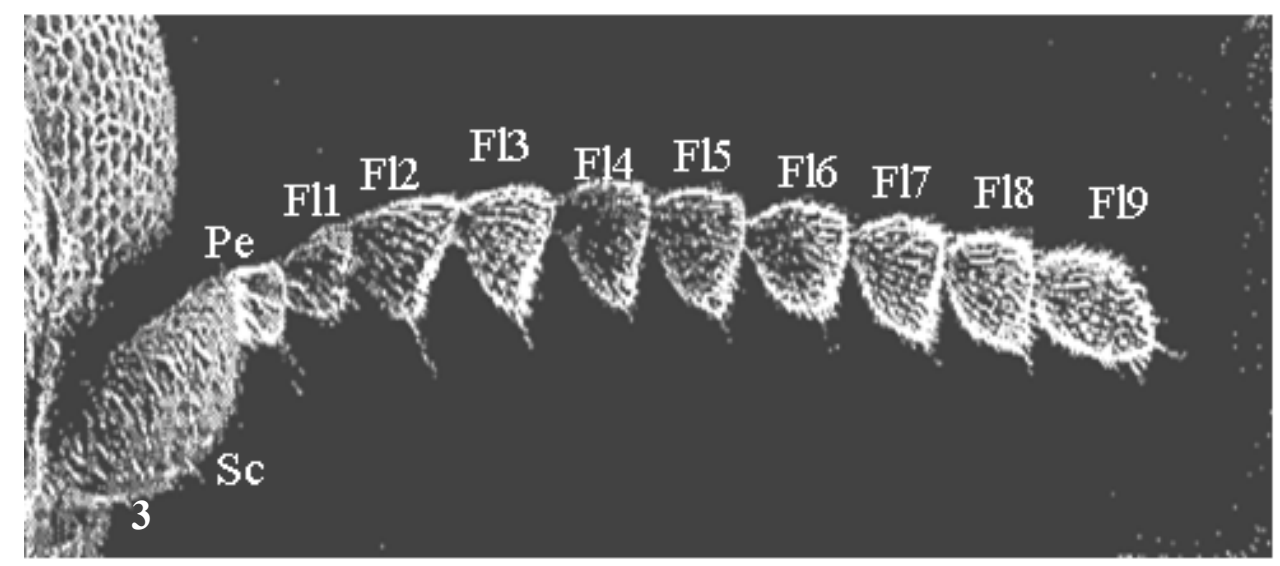

Fig.3: Scanning electron micrograph of antennal segments of untreated $L$. serricorne. Sc: Scape; Pe: Pedicel and F (1-9): Flagellar segments Scale bar: $300 \mu \mathrm{m}$. 


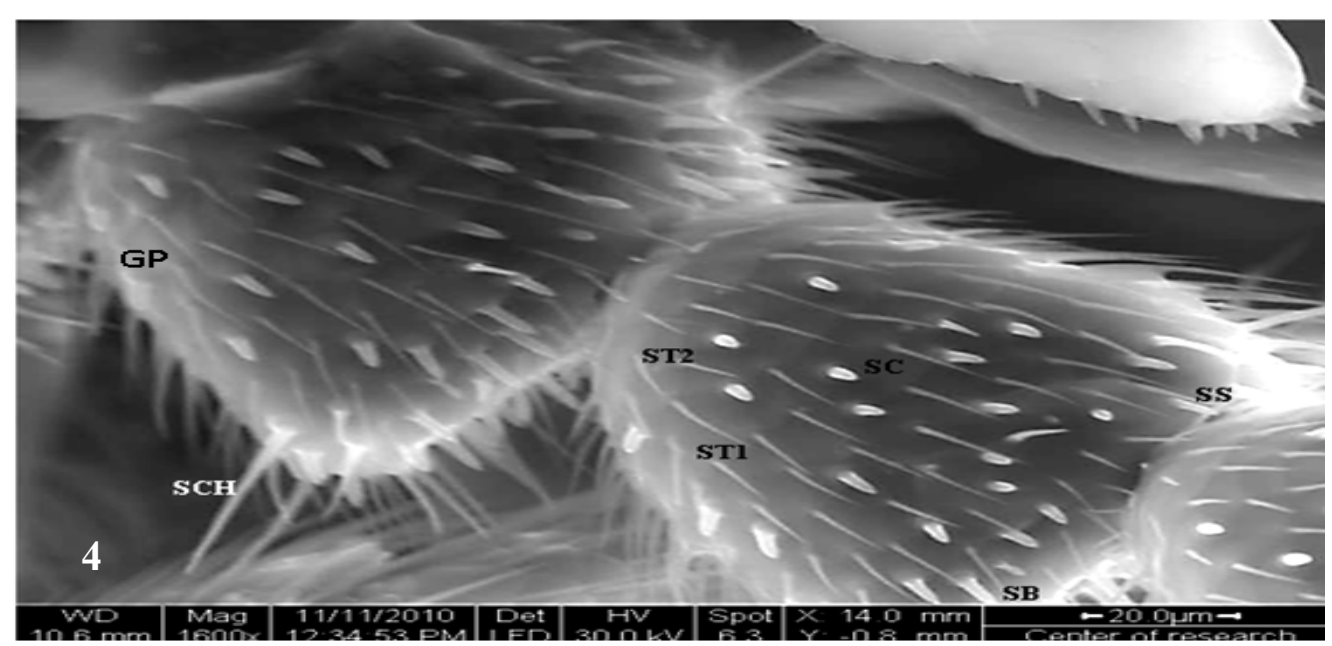

Fig. 4: Scanning electron micrograph of F1 6 and F17 showing ST1 (Sensilla trichoid 1) and ST2 (Sensilla trichoid 2), SC (Sensilla chaetica), SB (Sensilla basiconica, grooved pegs (GP).). Scale bar: 20 um.

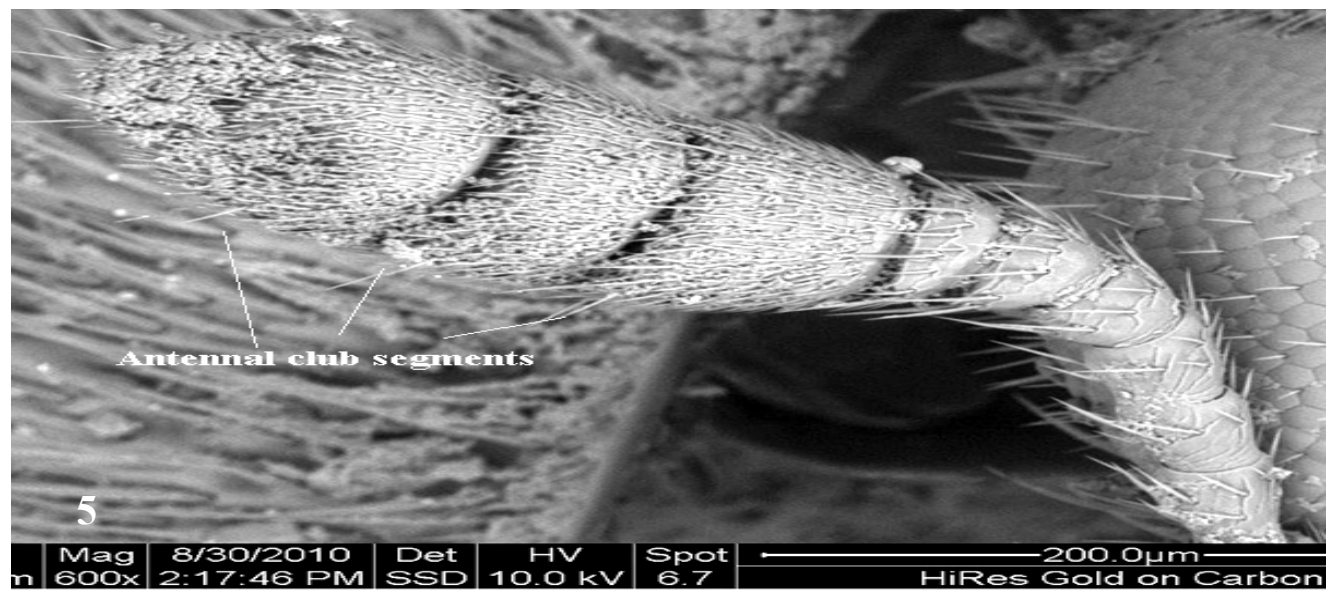

Fig.5: Scanning electron micrograph of antenna of adult resulted from treatment of 3rd instar larva of A. fasciatus.with peppermint oil, showing malformation and disorientation of the antennal structures. Scale bar: $200 \mathrm{um}$.

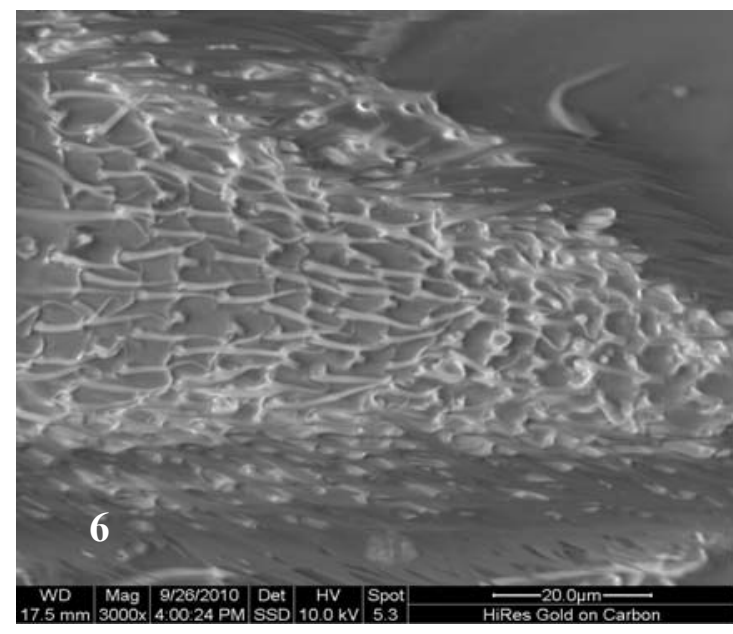

Fig. 6: Scanning electron micrograph of terminal antennal club of adult resulted from treatment of $3^{\text {rd }}$ instar larva of $A$. fasciatus with peppermint oil, showing malformation of antennal sensilla. Scale bar: $200 \mu \mathrm{m}$.

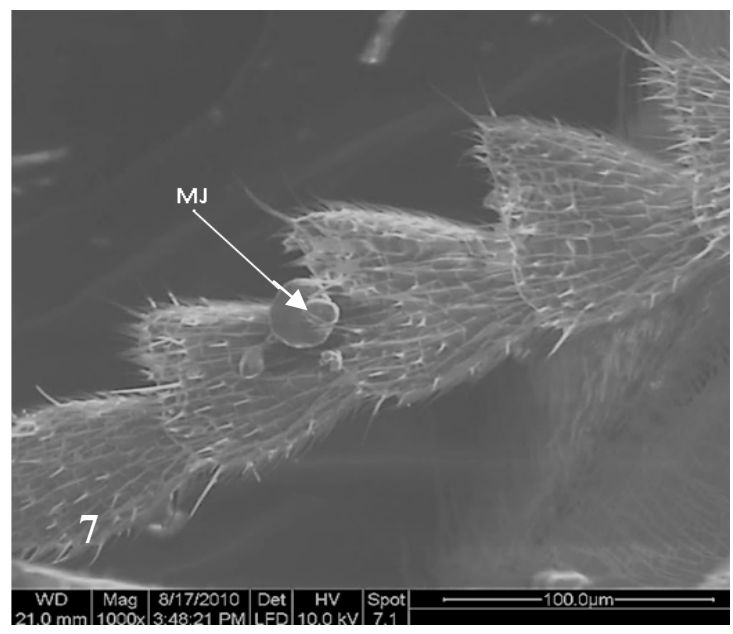

Fig.7: Scanning electron micrograph of flagellum of adult resulted from treatment of $3^{\text {rd }}$ instar larva of $L$. serricorne with peppermint oil, showing malformation of antennal sensilla. and enlarge membranous joint between segment 5 and 6 . Scale bar: $100 \mu \mathrm{m}$. 


\section{ARABIC SUMMARY}

النشاط السمي لبعض الزيوت النباتية الطيارة ضد حشرتين من آفات المتاحف
رضا فضيل على بكر' - هدى محمد عبدالفتاح' ـ نبيلة محمد سالم ـ نجوى حسن عطية

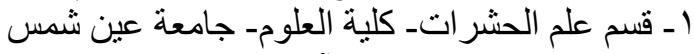

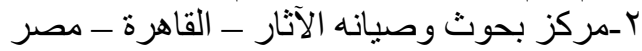

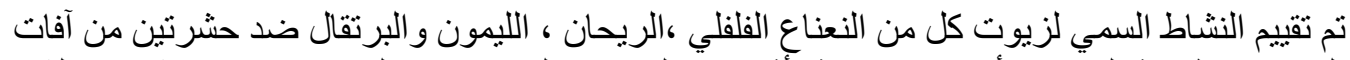

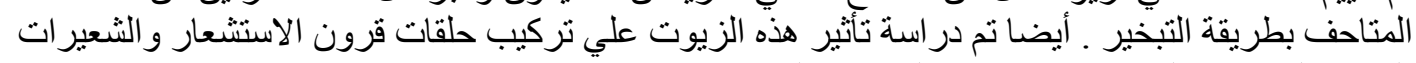
الحسية المصاحبة لها باستخدام جهاز الماسح الاليكتروني .

أوضحت النتائج أن زيت النعناع الفلفلي كان أكثر الزيوت سمية علي كل من اليرقات و الحشر ات الكاملة لخنفساء

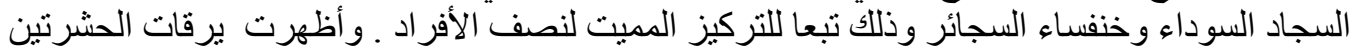

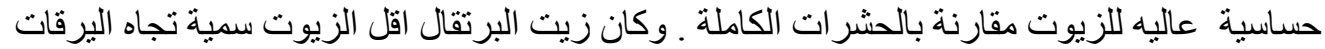

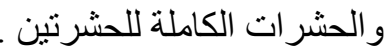
كما أدي معالجة العمر الثالث ليرقات كلتنا الحشرتين بالزيوت الطيارة إلي ظهور تشوهات وخلل في حلقات قرون

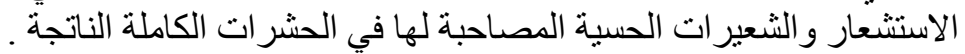

